\title{
Agronomic efficiency of intercropping tomato and lettuce
}

\author{
ARTHUR B. CECÍLIO FILHO ${ }^{1}$, BRÁULIO L.A. REZENDE ${ }^{2}$, \\ JOSÉ C. BARBOSA ${ }^{3}$ and LEILSON C. GRANGEIRO ${ }^{4}$ \\ ${ }^{1}$ Universidade Estadual Paulista/UNESP, Departamento de Produção Vegetal, \\ Via de acesso Prof. Paulo D. Castellane, s/n, 14884-900 Jaboticabal, SP, Brasil \\ ${ }^{2}$ Universidade Estadual de Ponta Grossa/ UEPG, Departamento de Fitotecnia e Fitossanidade, \\ Av. Carlos Cavalcanti, 4.748, 84030-900 Ponta Grossa, PR, Brasil \\ ${ }^{3}$ Universidade Estadual Paulista/UNESP, Departamento de Ciências Exatas, \\ Via de acesso Prof. Paulo D. Castellane, s/n, 14884-900 Jaboticabal, SP, Brasil \\ ${ }^{4}$ Universidade Federal Rural do Semi-Árido, Departamento de Produção Vegetal, \\ BR 110, Km 47, 59625-900 Mossoró, RN, Brasil
}

Manuscript received on August 14, 2009; accepted for publication on March 3, 2011

\begin{abstract}
Four experiments were carried out at the São Paulo State University, Brazil, with the aim of determining the agronomic viability of intercropping tomato and lettuce, under greenhouse conditions. The studied intercropping systems were established by transplanting lettuce at $0,10,20$ and 30 days after transplanting (DAT) tomato and by transplanting tomato at 0,10, 20 and 30 DAT lettuce. Intercropped tomato and lettuce were evaluated during two seasons and compared to their sole cropping. The experimental design was a randomized complete block with nine treatments. The productivity and the classification of the tomato fruits were not influenced by having lettuce intercropped with it, but lettuce production was lowered when tomato was intercropped with it. The longer the delay in lettuce transplanting, the greater the reduction in its productivity. There was an effect of cropping season on the extent of the agronomic advantage of intercropping over sole cropping. In the first cropping season, intercropping established by transplanting lettuce during the interval between 30 days before up to 20 DAT tomato yielded land use efficiency (LUE) indices of 1.63 to 2.22 . In the second period, intercropping established with the transplanting of lettuce up to 30 days before tomato yielded LUE indices of 1.57 to 2.05 .
\end{abstract}

Key words: cropping systems, greenhouse, Lactuca sativa, Solanum lycopersicon, planting time.

\section{INTRODUCTION}

The growing demand for vegetables of high quality and likely to be found year-round in the market has contributed to investments in new cropping systems that permit the production of these vegetables in different regions, as well as under adverse environmental conditions. In Brazil, growing vegetables in greenhouses has won a place among growers due mainly to the relative ease of handling the cropping conditions when compared to conventional systems in the open field (Carrijo et al. 2004).

Correspondence to: Arthur Bernardes Cecílio Filho E-mail: rutra@fcav.unesp.br
Vegetable growers, however, concern themselves not only with productivity and the quality of the desired product, but also with the way to achieve it. The modus operandi should include planning to promote the reduction of costs in the production of vegetables, as well as to lower the impact on the environment. The repercussions will be noticed in the greater competitiveness of both product and producer in the market, as well as in the higher sustainability of the system.

In the last years, there was a great increase in the considering the relations between agriculture and the environment, natural resources and food quality (Ehlers 1999). In the past, growth in food production was 
achieved by using more land and, more recently, by the increase in productivity. Although the important contribution of these two tools should not be forgotten, intercropping can contribute directly and/or indirectly to the modern view of Agriculture, in addition to having special advantages related to the reduction of environmental impact and increased yields.

According to Trenbath (1975), in the former days, intercropping was preferred by farmers over sole cropping. The modernization and industrialization of Agriculture, which are necessary to increase food production, are thought to be the main causes of the preferential sole cultivation of several species. Nowadays the intercropping procedure is being reevaluated due to advantages pointed previously (Oliveira et al. 2005). Considering that the productivity of a crop is limited by the amount of resources and is mainly determined by how efficiently the crop can use them, the species composing an intercropping should be contrasting in some of their agrobotanical characteristics, such as size, architecture, cycle, growth rate, demand for nutrients, demand for light, etc.

Tomato and lettuce are of great economic importance in Brazil's vegetable market. They were chosen for this study because they match the very important, and perhaps the most important, criterion for achieving success under intercropping conditions, i.e., they are contrasting. Thus, one of the reasons for this choice of crops was to exploit their temporal and/or spatial complementarities.

Lettuce is a leafy vegetable cultivated nowadays in Brazil in an area of approximately 35,000 hectares. Among the groups of lettuce, the crisp variety without head formation is predominant in Brazil and represents about $70 \%$ of those found in the market (Costa 2005). Regarding tomatoes, Brazil, with a cultivated area of 56,986 ha, produced 3,347,650 $\mathrm{t}$ in 2004 , this being the 8 th highest production among the major producing countries (AGRIANUAL 2005).

The only scientific report on the intercropping of these two vegetables found in the literature is the one by Rezende et al. (2005). According to Debarba (2000), mentioned by Souza and Resende (2003), the association with tomato is beneficial for lettuce. However, this author did not mention the type of effect, if any, of lettuce on tomato. Rezende et al. (2003) determined the effect of aqueous extracts $(0,5,10$, and $100 \% \mathrm{w} / \mathrm{v})$ obtained from leaves of tomato plants of different ages $(0,14,28$, and 42 DAT) on seeds and seedlings of lettuce. No significant reduction was found in root dry matter (except for the leaf extract of 28 DAT tomato plants) and dry matter of the aerial part (except for the leaf extract of 42 DAT plants) of lettuce seedlings when the concentrations of the aqueous extracts were 5 and $10 \%$, in relation to those treated with distilled water. Similar results were obtained for the germination characteristics of seeds, length of roots and number of leaves of lettuce. However, with an $100 \%$ extract, the large majority of evaluated characteristics showed significantly lower values compared to the results with 5 and $10 \%$, extracts and distilled water. On the other hand, the allelopathic effect, which may be caused by exudation, volatilization, leaching or decomposition (Rice 1974), may occur - though to a lesser extent - when plants are growing in the field.

Rezende et al. (2005) observed that, in the intercropping of tomato and lettuce, the productivity of tomato was not reduced by lettuce in any of the times when intercropping was established (transplanting lettuce at $0,14,28$, and 42 DAT tomato). It was also verified that the presence of lettuce did not influence the classification of tomato fruits in relation to sole cropping. On the other hand, the authors observed that there was a decrease in the accumulation of fresh and dry weight of lettuce when intercropped with tomato, and that this negative effect increased when transplanting of lettuce was more delayed in relation to that of tomato.

Based on considerations these, four greenhouse experiments were carried out with the aim of determining the agronomic viability of intercropping lettuce and tomato in comparison to sole cropping, with this viability measured by the index of land use efficiency (LUE).

\section{MATERIALS AND METHODS}

The four experiments were carried out in two greenhouses of the arched roof model with a wall height of $3 \mathrm{~m}$, covered with a transparent polyethylene sheet of low density and thickness of $150 \mu \mathrm{m}$ activated against ultraviolet rays. The greenhouses are located at the UNESP campus of Jaboticabal, state of São Paulo, Brazil, at $575 \mathrm{~m} \mathrm{high,} 21^{\circ} 15^{\prime} 22^{\prime \prime} \mathrm{S}$ longitude and $48^{\circ} 15^{\prime} 58^{\prime \prime} \mathrm{W}$ latitude. 
The climate of Jaboticabal is classified as subtropical, rainy during the Summer and relatively dry in the Winter. The annual means for precipitation and temperature and maximal and minimal temperatures are, respectively, $1424.6 \mathrm{~mm}, 22.2^{\circ} \mathrm{C}, 28.9^{\circ} \mathrm{C}$ and $16.8^{\circ} \mathrm{C}$. The soil of the area corresponds to an eutroferric red latossol with a very clayey texture, moderately kaolinitic-oxidic, and the topography is mildly undulating to undulating.

The four experiments were conducted in two pairs, in two seasons. Experiment 1 took place from April 17 to September 9, 2003, when tomato was the main crop, followed by lettuce. The latter was transplanted at 0 , 10,20 and 30 DAT tomato. In each of these experiments, lettuce was also singly cultivated aiming to detect possible environment differences that could influence the behavior of plants. Experiment 2 took place between January 30 and May 27, 2004, and consisted of the same treatments as those of experiment 1 . In experiment 3, which was carried out from April 17 to September 23, 2003, tomato was the secondary crop and lettuce the main one. Transplantings in experiment 3 were made at the same time intervals used in experiments 1 and 2 . Experiment 4 took place from January 30 to June 24, 2004 , and consisted in a re-evaluation of the treatments of experiment 3 (Table I). Each experiment was carried out using a randomized complete block design. Experiments 1 and 2 had eight and five replications, respectively; experiments 3 and 4 were made with ten replications each.

The experimental units (plant beds) were made up of 10 plants of tomato and 40 plants of lettuce, totalizing an area of $3 \mathrm{~m}^{2}(1.20 \times 2.5 \mathrm{~m})$. The tomato and lettuce plants used for evaluating the characteristics under study were six and 20 plants taken from the central portion of the plant bed, respectively.

Prior to the beginning of the experiments, chemical analyses of the soil of greenhouses were performed and the results are given in Table II.

In the four experiments, liming and fertilizing the soil for the intercropping and sole cropping treatments of tomato were carried out based on the recommendations of Trani et al. (1997a). Calcined lime was used with a relative total neutralizing power of $122 \%$, along with the fertilizers ammonium nitrate, simple superphosphate and potassium chloride. Both for tomato and lettuce, fertilizer doses were applied by side-dressing, as recommended by Trani et al. (1997a, b).
Cultivars Debora Max $F_{1}$ and Vera of tomato and lettuce, respectively, were used in this experiment. Seedlings of tomato and lettuce were grown in 128 and 288 cell trays, respectively. Lettuce plantlets with four leaves above the cotyledons were transplanted to rows $0.30 \mathrm{~m}$ apart with a distance of $0.25 \mathrm{~m}$ between plantlets. Tomato plants, also with four leaves above the cotyledons, were transplanted so as to fit a spacing of $1.20 \mathrm{~m}$ between double rows, $0.60 \mathrm{~m}$ between single rows and $0.50 \mathrm{~m}$ between plants in a row.

Tomato and lettuce growth and harvesting periods in the different intercroppings and cropping seasons are shown in Tables III and IV.

The plants were staked with plastic strips and disposed perpendicularly to the ground. The strip was tied to wires placed parallel to the ground, the first one situated close to the ground and the second at a height of $2 \mathrm{~m}$. The upper wire was supported by poles and bamboo sticks. Pruning was always done when necessary, eliminating the smallest buds.

LUE index was calculated by the formula proposed by Harwood (1973) and cited by Hiebsch and McCollum (1987):

$$
L U E=\frac{Y_{1}^{c}}{Y_{1}^{m}}+\frac{Y_{2}^{c}}{Y_{2}^{m}}+\frac{Y_{n}^{c}}{Y_{n}^{m}} \text { then } \sum_{i=1}^{n} Y c, i / Y m, i
$$

where: $Y c, i=$ the productivity of crop "i" in the intercropping (c), and $Y m, i=$ the productivity of crop "i" when cropped singly $(\mathrm{m})$.

A combined analysis for each cropping season of the experiments of transplanting lettuce after tomato and of transplanting tomato after lettuce was conducted, and the comparison of the means of the cropping season and transplanting times was made by means of the Tukey test. Later, a regression analysis was performed for the LUE index, in each cropping season, according to the transplanting times of lettuce ( -30 to +30 days) in relation to tomato, which correspond to the whole duration of the four experiments. Thus, the treatments of experiments 3 and 4 , that is, those in which tomato was transplanted at $0,10,20$ and 30 DAT lettuce were considered, for the purpose of the statistical analysis, as correspondents, respectively, to $0,-10,-20$ and -30 days from transplanting lettuce in relation to tomato. 
TABLE I

Characterization of the treatments of intercropping tomato and lettuce, with lettuce established after tomato (experiments 1 and 2 ) and tomato after lettuce (experiments 3 and 4$)$.

\begin{tabular}{c|c|c|c|c}
\hline \multirow{2}{*}{ Treatments } & \multicolumn{2}{|c|}{ Experiments 1 and 2 } & \multicolumn{2}{c}{ Experiments 3 and 4 } \\
\cline { 2 - 5 } & Tomato & Lettuce (DAT*) & Lettuce & Tomato (DAT*) \\
\hline 1 & Present & 0 & Present & 0 \\
2 & Present & 10 & Present & 10 \\
3 & Present & 20 & Present & 20 \\
4 & Present & 30 & Present & 30 \\
5 & Present & Absent & Present & Absent \\
6 & Absent & 0 & Absent & 0 \\
7 & Absent & 10 & Absent & 10 \\
8 & Absent & 20 & Absent & 20 \\
9 & Absent & 30 & Absent & 30 \\
\hline
\end{tabular}

*days after the transplanting of the primary crop.

\section{TABLE II}

Results of chemical analyses of the greenhouse soil, prior to the four experiments.

\begin{tabular}{c|c|c|c|c|c|c|c|c|c}
\hline \multirow{2}{*}{ Experiments } & $\mathrm{pH}$ & $\mathrm{O}$ & $\mathrm{M}$ & $\mathrm{P}$ resin & $\mathrm{K}$ & $\mathrm{Ca}$ & $\mathrm{Mg}$ & $\mathrm{H}+\mathrm{Al}$ & $\mathrm{V}$ \\
\cline { 5 - 7 } & $\mathrm{CaCl}_{2}$ & $\mathrm{~g} / \mathrm{dm}^{3}$ & $\mathrm{mg} / \mathrm{dm}^{3}$ & \multicolumn{5}{|c|}{$\mathrm{mmol}_{c} \mathrm{dm}^{-3}$} & \\
\hline 1 & 5.7 & 22 & 138 & 2,4 & 51 & 21 & 22 & 77 \\
2 & 5.8 & 18 & 67 & 1,2 & 32 & 8 & 28 & 60 \\
3 & 5.3 & 20 & 88 & 2,6 & 29 & 13 & 28 & 61 \\
4 & 6.3 & 18 & 143 & 2,5 & 52 & 20 & 20 & 79 \\
\hline
\end{tabular}

O.M. = organic matter.

TABLE III

Transplanting, harvesting, and growth periods (GP) of lettuce (L) and tomato $(T)$ of experiments 1 and 2 , characterized by the transplanting of lettuce after tomato, in two cropping seasons.

\begin{tabular}{|c|c|c|c|c|c|c|}
\hline \multirow{3}{*}{ Cropping system } & \multicolumn{6}{|c|}{ First season (April 17 to September 9, 2003) } \\
\hline & \multicolumn{2}{|c|}{ Transplant date } & \multicolumn{2}{|c|}{ Crop date } & \multicolumn{2}{|c|}{ GP (days) } \\
\hline & $\mathrm{L}$ & $\mathrm{T}$ & $\mathrm{L}^{* *}$ & $\mathrm{~T}^{* * *}$ & $\mathrm{~L}$ & $\mathrm{~T}$ \\
\hline T + L 0 DATT* & $4-17$ & - & $6-2$ & $9-9$ & 46 & 145 \\
\hline $\mathrm{T}+\mathrm{L} 10$ DATT & $4-27$ & - & $6-17$ & $9-9$ & 51 & 143 \\
\hline $\mathrm{T}+\mathrm{L} 20$ DATT & $5-7$ & - & $6-27$ & $9-9$ & 51 & 137 \\
\hline $\mathrm{T}+\mathrm{L} 30$ DATT & $5-17$ & - & $7-8$ & $9-9$ & 51 & 136 \\
\hline T sole cropping & - & 4-17 & - & $9-9$ & - & 145 \\
\hline \multirow{3}{*}{ Cropping system } & \multicolumn{6}{|c|}{ Second season (January 30 to May 27,2004 ) } \\
\hline & \multicolumn{2}{|c|}{ Transplant date } & \multicolumn{2}{|c|}{ Crop date } & \multicolumn{2}{|c|}{ GP (days) } \\
\hline & $\mathrm{L}$ & $\mathrm{T}$ & $\mathrm{L}^{* *}$ & $\mathrm{~T}^{* * *}$ & $\mathrm{~L}$ & $\mathrm{~T}$ \\
\hline T + L 0 DATT* & $1-30$ & - & $3-13$ & $5-27$ & 43 & 117 \\
\hline $\mathrm{T}+\mathrm{L} 10$ DATT & $2-9$ & - & $3-19$ & $5-27$ & 39 & 117 \\
\hline $\mathrm{T}+\mathrm{L} 20$ DATT & $2-19$ & - & $3-29$ & $5-27$ & 39 & 117 \\
\hline $\mathrm{T}+\mathrm{L} 30 \mathrm{DATT}$ & $3-1$ & - & $4-15$ & $5-27$ & 45 & 117 \\
\hline T sole cropping & - & $1-30$ & - & $5-27$ & - & 117 \\
\hline
\end{tabular}

*days after the transplanting of tomato; **singly cultivated lettuce plots were harvested at the same dates as those submitted to intercropping; ${ }^{* * *}$ date of the last harvest. 
TABLE IV

Transplanting, harvesting, and growth periods (GP) of lettuce (L) and tomato (T) of experiments 3 and 4, characterized by the transplanting of tomato after lettuce, in two cropping seasons.

\begin{tabular}{l|c|c|c|c|c|c}
\hline \multirow{2}{*}{ Cropping system } & \multicolumn{5}{|c}{ First season (April 17 to September 9, 2003) } \\
\cline { 2 - 7 } & Transplant date & Crop date & \multicolumn{2}{|c}{ GP (days) } \\
\cline { 2 - 7 } & $\mathrm{L}$ & $\mathrm{T}$ & $\mathrm{L} * *$ & $\mathrm{~T} * * *$ & $\mathrm{~L}$ & $\mathrm{~T}$ \\
\hline L + T 0 DATL* & - & $4-17$ & $6-2$ & $9-14$ & 46 & 152 \\
L + T 10 DATL* & - & $4-27$ & $6-2$ & $9-23$ & 46 & 149 \\
L + T 20 DATL* & - & $5-7$ & $6-2$ & $9-23$ & 46 & 139 \\
L + T 30 DATL* & - & $5-17$ & $6-2$ & $9-23$ & 46 & 129 \\
L sole cropping & $4-17$ & - & $6-2$ & - & 46 & - \\
\hline \multirow{4}{*}{ Cropping system } & \multicolumn{7}{|c}{ Second season (January 30 to May 27, 2004) } \\
\cline { 2 - 7 } & Transplant date & Crop date & \multicolumn{2}{|c}{ GP (days) } \\
\cline { 2 - 7 } & $\mathrm{L}$ & $\mathrm{T}$ & $\mathrm{L}$ & $\mathrm{T}$ & $\mathrm{L}$ & $\mathrm{T}$ \\
\hline L + T 0 DATL* & - & $30-1$ & $3-13$ & $6-3$ & 42 & 125 \\
L + T 10 DATL* & - & $9-2$ & $3-13$ & $6-10$ & 42 & 122 \\
L + T 20 DATL* & - & $19-2$ & $3-13$ & $6-17$ & 42 & 119 \\
L + T 30 DATL* & - & $1-3$ & $3-13$ & $6-24$ & 42 & 116 \\
L sole cropping & $30-1$ & - & $3-13$ & - & 42 & - \\
\hline
\end{tabular}

*days after the transplanting of lettuce; **singly cultivated lettuce plots were harvested at the same dates as those submitted to intercropping; ***date of the last harvest.

TABLE V

F values, significance and coefficients of variation of the land use efficiency (LUE) index, from the combined analysis of variance (cultivation periods: April 17 to September 9, 2003, and January 30 to July 25, 2004) of experiments in which lettuce was transplanted after tomato, and in experiments in which tomato was transplanted after lettuce.

\begin{tabular}{c|c|c}
\hline \multirow{2}{*}{ Variation causes } & \multicolumn{2}{|c}{ Land use efficiency } \\
\cline { 2 - 3 } & Lettuce after tomato & Tomato after lettuce \\
\hline Season (S) & $88.65^{* *}$ & $15.77^{* *}$ \\
Transplanting time (TT) & $14.85^{\mathrm{ns}}$ & $0.46^{\mathrm{ns}}$ \\
$\mathrm{S} \times \mathrm{TT}$ & $6.00^{* *}$ & $2.76^{*}$ \\
$\mathrm{CV}(\%)$ & 12.4 & 13.3 \\
\hline
\end{tabular}

$* \mathrm{P}<0.05 ; * * \mathrm{P}<0.01 ; \mathrm{ns}=$ non significant at the level of $5 \%$ of probability.

\section{RESULTS AND DISCUSSION}

For the intercropping resulting from the transplanting of lettuce after tomato, the combined analysis of variance of the experiments conducted in two growing periods showed that the values of the LUE index (Table V) were significantly influenced by the interaction of cropping season and transplanting time.

In the first cropping season, except for the intercropping established with the transplanting of lettuce at 30 DAT tomato, the indices showed that, as to food production, intercropping as compared to sole cropping, was significantly advantageous (Table VI). In intercroppings with transplanting lettuce up to 10 DAT tomato, the LUE index was 1.85. Therefore, to obtain the same amount of food as that produced in 1 ha of intercropping, it would be necessary an area of 1.85 ha of tomato and lettuce or, in other words, 0.925 ha for each species in sole cropping. Rezende et al. (2005) also observed a greater LUE (between 1.61 and 1.73) with intercrop- 
TABLE VI

Productivity of tomato $(T)$ and lettuce $(L)$ in intercropping and in sole cropping; relative efficiency indices of the crop components of intercropping (RET and REL for tomato and lettuce, respectively) and land use efficiency index (LUE). First cropping season: April 17 to September 9, 2003.

\begin{tabular}{l|c|c|c|c|c}
\hline \multirow{2}{*}{ Cropping system } & \multicolumn{5}{|c}{ Productivity $\left(\mathrm{kg} \mathrm{ha}^{-1}\right)$} \\
\cline { 2 - 6 } & $\mathrm{T}$ & $\mathrm{L}$ & $\mathrm{RET}$ & $\mathrm{REL}$ & $\mathrm{LUE}$ \\
\hline Intercropping & & & & & \\
\hline $\mathrm{T}+\mathrm{L}$ 0 DATT* & $206,664.60 \mathrm{~A}$ & $17,025.53 \mathrm{~A}^{* *}$ & 1.01 & 0.84 & $1.85 \mathrm{~A}$ \\
$\mathrm{~T}+\mathrm{L} 10$ DATT & $201,464.65 \mathrm{~A}$ & $19,348.18 \mathrm{~A}$ & 0.99 & 0.86 & $1.85 \mathrm{~A}$ \\
$\mathrm{~T}+$ L 20 DATT & $192,309.18 \mathrm{~A}$ & $15,851.21 \mathrm{AB}$ & 0.94 & 0.69 & $1.63 \mathrm{~A}$ \\
$\mathrm{~T}+$ L 30 DATT & $204,575.73 \mathrm{~A}$ & $9,252.46 \mathrm{~B}$ & 1.00 & 0.36 & $1.36 \mathrm{~B}$ \\
\hline Sole cropping & & & & & \\
\hline T & $203,686.85 \mathrm{~A}$ & - & - & - & - \\
L 0 DATT & - & $20,203.58 \mathrm{~b} * * *$ & - & - & - \\
L 10 DATT & - & $22,411.83 \mathrm{ab}$ & - & - & - \\
L 20 DATT & - & $22,886.76 \mathrm{ab}$ & - & - & - \\
L 30 DATT & - & $25,708.60 \mathrm{a}$ & - & - & - \\
\hline
\end{tabular}

*DATT $=$ days after the transplanting of tomato; **Means, in each column, followed by the same capital letter, are not significantly different at the $5 \%$ level of probability, according to the Tukey's test; ***Means, in each column, followed by the same small case letter, are not significantly different at the $5 \%$ level of probability, according to the Tukey's test.

pings of lettuce and tomato when transplanting was carried out even close to the transplanting of tomato. They showed that transplanting lettuce 14 DAT tomato resulted in a substantial reduction in the production of the intercropping and, consequently, in LUE, which lowered to 1.24 for transplantings carried out 28 days after tomato.

Even with the intercropping established with the transplanting of lettuce 20 DAT tomato, the LUE was high $(63 \%)$ probably due to the fact that, in this case, relative efficiency of productivity of lettuce in intercropping was $69 \%$ of that when sole cropped. However, the relative efficiency of lettuce in intercropping increased to $86 \%$ when intercropping was initiated at 10 DAT.

The reduction in the relative efficiency of lettuce in intercropping (Table VI) with later transplanting in relation to tomato demonstrated the harm it underwent due to its growth taking place in a more advanced period of the cycle of the tomato plants. This happens because tomato shading the lettuce plants hampered several of their biosynthetic processes, thus leading to a lower accumulation of mass. The loss of almost 30\% in productivity of lettuce in intercropping established with its transplanting starting at 20 DAT of tomato in relation to that produced in sole cropping, reached up to $64 \%$ when the intercropping was established 10 days later. According to Andriolo (2000), the most important component of the environment influencing the process of plant production is sunlight. The insufficient access of shaded plants to sunlight due to the occupation of the space by the dominant crop may lead to serious harm to the first, with sometimes lethal effects (Sinoquet and Caldwell 1995). Productivity depends on the total production of biomass and its distribution different parts of the plant. Shading of a crop by the primary crop in intercropping reduces photosynthetic activity in the shaded plants, resulting in lower growth and productivity (Fukai and Trenbath 1993).

Tomato contributed more than lettuce to the achievement of elevated LUE indices. Its participation in the index was greater when intercropping was established by the late transplanting of lettuce: it was of $54 \%$ when lettuce was transplanted up to 10 DAT tomato, 
TABLE VII

Productivity of tomato ( $T$ ) and lettuce $(\mathrm{L})$ in intercropping and in sole cropping; relative efficiency indices of the crop components of intercropping (RET and REL for tomato and lettuce, respectively) and land use efficiency index (LUE). Second cropping season: January 30 to July 25, 2004

\begin{tabular}{l|c|c|c|c|c}
\hline \multirow{2}{*}{ Cropping system } & \multicolumn{5}{|c}{ Productivity $\left(\mathrm{kg} \mathrm{ha}^{-1}\right)$} \\
\cline { 2 - 6 } & $\mathrm{T}$ & $\mathrm{L}$ & $\mathrm{RET}$ & $\mathrm{REL}$ & $\mathrm{LUE}$ \\
\hline Intercropping & & & & & \\
\hline $\mathrm{T}+\mathrm{L} 0$ DATT* & $137,776.40 \mathrm{~A}$ & $9,853.92 \mathrm{~A}^{* *}$ & 0.94 & 0.50 & $1.44 \mathrm{~A}$ \\
$\mathrm{~T}+$ L 10 DATT & $131,376.46 \mathrm{~A}$ & $3,969.30 \mathrm{~B}$ & 0.90 & 0.27 & $1.17 \mathrm{~B}$ \\
$\mathrm{~T}+$ L 20 DATT & $133,332.00 \mathrm{~A}$ & $2,911.98 \mathrm{~B}$ & 0.91 & 0.22 & $1.13 \mathrm{~B}$ \\
$\mathrm{~T}+$ L 30 DATT & $144,398.55 \mathrm{~A}$ & $3,102.64 \mathrm{~B}$ & 0.98 & 0.26 & $1.24 \mathrm{~B}$ \\
\hline Sole cropping & & & & & \\
\hline T & $146,620.75 \mathrm{~A}$ & - & - & - & - \\
L 0 DATT & - & $19,664.52 \mathrm{a} * * *$ & - & - & - \\
L 10 DATT & - & $14,585.89 \mathrm{~b}$ & - & - & - \\
L 20 DATT & - & $13,060.57 \mathrm{~b}$ & - & - & - \\
L 30 DATT & - & $12,133.24 \mathrm{~b}$ & - & - & - \\
\hline
\end{tabular}

*DATT $=$ days after the transplanting of tomato. ${ }^{* *}$ Means, in each column, followed by the same capital letter, are not significantly different at the $5 \%$ level of probability, according to the Tukey's test; ***Means, in each column, followed by the same small case letter, are not significantly different at the $5 \%$ level of probability, according to the Tukey's test.

and $73.5 \%$ when lettuce transplanting took place at 30 DAT. In the first cropping season, lettuce in intercropping showed a high relative efficiency of $86 \%$ when transplanted up to 10 days after tomato in relation to its sole cultivation. On the other hand, lettuce plants of intercroppings established with transplanting at 30 DAT tomato had an etiolated appearance, with fewer leaves and leaf stem narrow and long, thus without quality for commercial purposes. Therefore, intercropping established in this season is not recommended, even though it shows an elevated LUE index (1.36), which would characterize a productivity advantage of intercropping over sole cropping.

In the second cropping season (Table VII), the indices were much lower than those of the first one. This was probably due to the greater number of rainy days (69 days) and shorter period of sun (1,275.8 h) in this cropping season compared to the first planting (27 days of rain and $1547 \mathrm{~h}$ of sun). The highest LUE value (1.44) was obtained when intercropping was established with the transplanting of the crops on the same day. From this point onwards, the land use effi- ciency showed a marked reduction with a variation of 13 to $24 \%$ higher than that for sole cropping. In intercropping systems established with the transplanting of lettuce after 20 DAT tomato, the commercial traits of lettuce yields were not considered adequate. These results were similar to those installed 10 days later (30 DAT tomato).

As in the first planting, tomato crop had a greater contribution in composing the LUE index $(65 \%$ in the intercropping at 0 DAT and $79 \%$ in that established at 30 DAT). A small increase in the LUE index was observed between the intercroppings established at 10 and 30 DAT, which was due to the increase in the productivity of tomato.

Considering that in intercropping the aim is to maximize the productivity of the crops and that, in the second cultivation, the productivity of lettuce was markedly lowered (37\%) when its transplanting was delayed 10 days after tomato (from 0 to $10 \mathrm{DAT}$ ) (Table VII), the recommendation of this experiment is that high yields are to be expected only when the crops are transplanted on the same day. 
TABLE VIII

Productivity of lettuce ( $L$ ) and tomato $(T)$ in intercropping and in sole cropping; relative efficiency indices of the crop components of intercropping (RET and REL for tomato and lettuce, respectively) and land use efficiency index (LUE). First cropping season: April 17 to September 9, 2003.

\begin{tabular}{l|c|c|c|c|c}
\hline \multirow{2}{*}{ Cropping system } & \multicolumn{5}{|c}{ Productivity $\left(\mathrm{kg} \mathrm{ha}^{-1}\right)$} \\
\cline { 2 - 6 } & $\mathrm{T}$ & $\mathrm{L}$ & $\mathrm{RET}$ & $\mathrm{REL}$ & LUE \\
\hline Intercropping & & & & & \\
\hline L + T 0 DATL* & $212,597.87 \mathrm{~A}^{* *}$ & $25,784.00 \mathrm{~A}$ & 1.00 & 1.04 & $2.04 \mathrm{~A}$ \\
L + T 10 DATL & $207,353.48 \mathrm{~A}$ & $27,494.79 \mathrm{~A}$ & 1.00 & 1.11 & $2.11 \mathrm{~A}$ \\
L + T 20 DATL & $207,486.81 \mathrm{~A}$ & $23,701.42 \mathrm{~A}$ & 1.00 & 0.95 & $1.95 \mathrm{~A}$ \\
L + T 30 DATL & $207,175.70 \mathrm{~A}$ & $25,535.27 \mathrm{~A}$ & 1.00 & 1.03 & $2.03 \mathrm{~A}$ \\
\hline Sole cropping & & & & & \\
\hline L & - & $24,862.74 \mathrm{~A}$ & - & - & - \\
T 0 DATL & $212,597.87 \mathrm{a} * * *$ & - & - & - & - \\
T 10 DATL & $207,353.48 \mathrm{a}$ & - & - & - & - \\
T 20 DATL & $207,486.81 \mathrm{a}$ & - & - & - & - \\
T 30 DATL & $207,175.70 \mathrm{a}$ & - & - & - & - \\
\hline
\end{tabular}

*DATL $=$ days after the transplanting of lettuce. ${ }^{* *}$ Means, in each column, followed by the same capital letter, are not significantly different at the $5 \%$ level of probability, according to the Tukey's test; ***Means, in each column, followed by the same small case letter, are not significantly different at the $5 \%$ level of probability, according to the Tukey's test.

According to the LUE indices shown by the intercroppings installed with the transplanting of lettuce up to 10 DAT tomato for the first cropping season (Table VI), and 0 DAT for the second one (Table VII), intercropping of these two species can be considered advantageous compared to their sole cropping. Tomato and lettuce, under some of the conditions studied in this experiment, showed great complementarity in the use of available resources of the environment rather than interspecific competition.

For those cropping systems established with the transplanting of tomato after lettuce, the combined analysis of variance of experiments carried out in both growing seasons showed a significant interaction $(\mathrm{P}=$ $0,05)$ of the cropping season and time of transplanting tomato in relation to lettuce, that is, from the beginning of the intercropping (Table V).

In the first cropping season, the LUE indices were very high, between 1.95 and 2.11 (Table VIII) compared to 1.76 to 1.95 for the second season (Table IX), which correspond to increases in land use efficiency between 76 and $111 \%$. Jett et al. (2005) found an LUE index of 1.4 when tomato was transplanted soon after the sowing of lettuce.

The relative contributions of tomato and lettuce to the LUE indices of the intercroppings established at 0 , 10,20 , and 30 DAT lettuce were of 49 and $51 \%, 47$ and $53 \%, 51$ and $49 \%$, and 49 and $51 \%$, respectively. Thus, lettuce showed, with the exception of the intercropping established at 20 DAT lettuce, greater contributions to the composition of the LUE indices. In the second cropping season (January 30 to June 24, 2004), lettuce contributed with $43,44,49$, and $49 \%$, respectively, to the LUE indices of the intercroppings established at $0,10,20$ and 30 DAT of lettuce. Thus, under these conditions and also when the intercroppings were established with the transplanting of lettuce after tomato, the contribution of tomato was always greater than that of lettuce to the indices.

The delay in the transplanting of tomato contributed to increase lettuce productivity, permitting it to reach levels comparable to those of lettuce singly cultivated that contributed to increase the LUE indices. However, when tomato was placed close to lettuce, the LUE 
TABLE IX

Productivity of lettuce (L) and tomato ( $T$ ) in intercropping and in sole cropping; relative efficiency indices of the crop components of intercropping (RET and REL for tomato and lettuce, respectively) and land use efficiency index (LUE). Second cropping season: January 30 to July 25, 2004.

\begin{tabular}{l|c|c|c|c|c}
\hline \multirow{2}{*}{ Cropping system } & \multicolumn{5}{|c}{ Productivity $\left(\mathrm{kg} \mathrm{ha}^{-1}\right)$} \\
\cline { 2 - 6 } & $\mathrm{T}$ & $\mathrm{L}$ & $\mathrm{RET}$ & $\mathrm{REL}$ & LUE \\
\hline Intercropping & & & & & \\
\hline L + T 0 DATL* & $136,265.30 \mathrm{~A}^{* *}$ & $14,403.89 \mathrm{~B}$ & 1.00 & 0.76 & $1.76 \mathrm{~A}$ \\
L + T 10 DATL & $122,665.44 \mathrm{~A}$ & $14,928.22 \mathrm{~B}$ & 1.00 & 0.79 & $1.79 \mathrm{~A}$ \\
L + T 20 DATL & $125,109.86 \mathrm{~A}$ & $17,905.20 \mathrm{~A}$ & 1.00 & 0.95 & $1.95 \mathrm{~A}$ \\
L + T 30 DATL & $137,109.74 \mathrm{~A}$ & $18,022.19 \mathrm{~A}$ & 1.00 & 0.95 & $1.95 \mathrm{~A}$ \\
\hline Sole cropping & & & & & \\
\hline L & - & $18,940.85 \mathrm{~A}$ & - & - & - \\
T 0 DATL & $136,265.30 \mathrm{a} * * *$ & - & - & - & - \\
T 10 DATL & $122,665.44 \mathrm{a}$ & - & - & - & - \\
T 20 DATL & $125,109.86 \mathrm{a}$ & - & - & - & - \\
T 30 DATL & $137,109.74 \mathrm{a}$ & - & - & - & - \\
\hline
\end{tabular}

*DATL $=$ days after the transplanting of lettuce. ${ }^{*}$ Means, in each column, followed by the same capital letter, are not significantly different at the $5 \%$ level of probability, according to the Tukey's test; ***Means, in each column, followed by the same small case letter, are not significantly different at the $5 \%$ level of probability, according to the Tukey's test.

indices did not differ significantly. Thus, the intercroppings with the transplanting of tomato on the same day as lettuce resulted in high LUE indices and may therefore be recommended to producers.

For each cropping season, a regression analysis of the LUE indices was performed. These indices resulted from the transplanting of lettuce ( -30 to +30 days) in relation to the transplanting of tomato. It was found that, in the first cropping season, there was a quadratic fit of the values obtained for the land use efficiency. The latter together, with intercropping, was more than $100 \%$ higher than in sole cropping when intercropping was installed with transplantings of seedlings before and up to the same day of tomato transplanting (Fig. 1). From this point onward, as the period between the transplanting of lettuce in relation to the transplanting of tomato increased to 10,20 , and 30 days, efficiency declined to 87,63 and $32 \%$, respectively.

In the second cropping season, the fit was linear (Fig. 1), demonstrating that there was a real difference of environment on the interaction of the crops. In intercroppings established with the transplanting of lettuce
30 days before tomato, land use efficiency was 105\% more than that of the sole cropping, similar to what was observed in the first cropping season under the same conditions of intercropping. However, as lettuce transplanting was closer to that of tomato, efficiency decreased to $57 \%$ when intercropping was established with the transplanting of both crops on the same day.

The results herein reported are an indication that the recommendation of intercropping tomato and lettuce must consider the cultivation season. The transplanting time was shown to be an effective factor in increasing land use efficiency. Based on the indices, the advantage of intercropping over sole cropping, both in terms of productivity and the maintenance of product quality, guarantees the recommendation of this cropping system to vegetable growers. However, for the first cropping season, the transplanting time for lettuce may vary from 30 days before up to 20 days after tomato transplanting, whereas in the second season, the transplanting period is much shorter, that is between 0 and 30 days before the transplanting of tomato.

There was an effect of cropping season on the land 


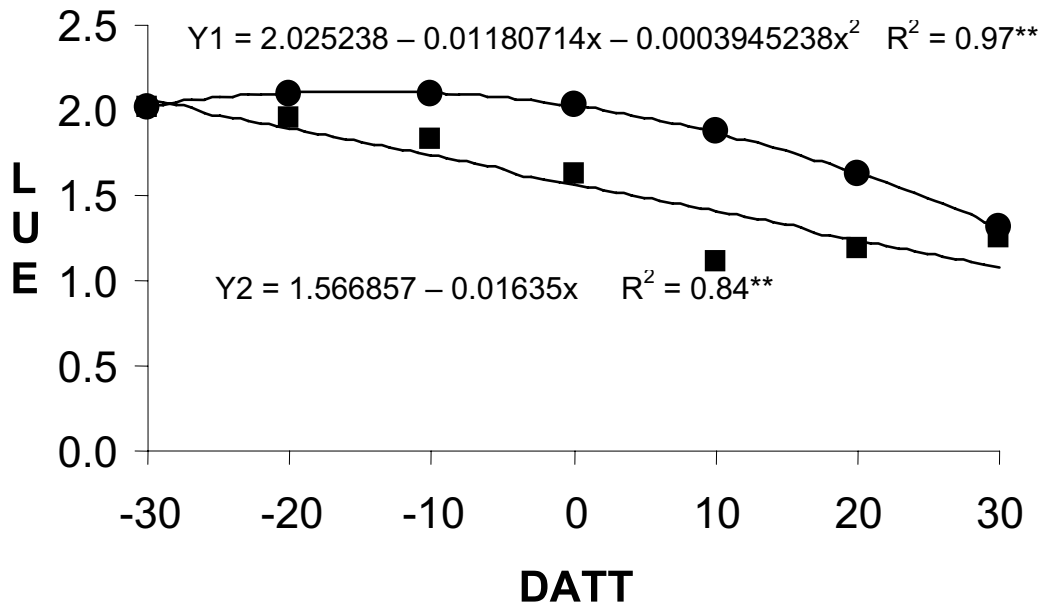

Fig. 1 - Land use efficiency (LUE) as a function of the number of days between the transplanting of lettuce in relation to tomato (days after transplanting of tomato, DATT), in the first (Y1) and second (Y2) cropping seasons.

use efficiency and, consequently, on the extent of agronomic advantage of intercropping as compared to sole cropping. In the cropping season from April to September, intercropping established with the transplanting of lettuce 30 days before up to 20 days after the transplanting of tomato yielded a land use efficiency between 63 and $122 \%$ higher than in sole cropping. In the cropping season from January to June, intercropping established with the transplanting of lettuce before tomato up to 30 days, gave a land use efficiency between 57 and 105\% higher than that of sole cropping. Then, the intercropping established in the above-mentioned periods in both cropping seasons, was shown to be agronomically viable in relation to their sole cropping, and may thus be recommended.

\section{RESUMO}

Quatro experimentos foram conduzidos na Unesp, Brasil, com o objetivo de determinar a viabilidade agronômica de cultivos consorciados de alface e tomate em ambiente protegido. Consórcios estabelecidos por transplantes da alface aos $0,10,20$ e 30 dias após o transplante (DAT) do tomate e de tomate aos $0,10,20$ e 30 DAT da alface, foram avaliados em duas épocas e comparados às suas monoculturas. Cada experimento foi conduzido em delineamento de blocos ao acaso, com nove tratamentos. Verificou-se que a produtividade do tomate e a classificação dos frutos não foram influenciadas pela alface, mas a produção da alface foi menor em consórcio. Quanto mais atrasado o transplante da alface menor foi a sua produtividade. Houve efeito de época de cultivo sobre a dimensão da vantagem agronômica do consórcio sobre a monocultura. Na primeira época de cultivo, os consórcios estabelecidos com o transplante da alface de 30 dias antes e até 20 dias após o transplante do tomate proporcionaram índices de eficiência do uso da área (EUA) de 1,63 a 2,22. Na segunda época, os consórcios estabelecidos com o transplante da alface antes do tomate, em até 30 dias, proporcionaram índices EUA de 1,57 a 2,05.

Palavras-chave: sistemas de cultivo, cultivo protegido, Lactuca sativa, Solanum lycopersicon, época de plantio.

\section{REFERENCES}

AGRIANUAL. 2005. Anuário da agricultura brasileira. FNP Consultoria \& AgroInformativos, São Paulo, p. 495-502.

ANDRIOLO JL. 2000. Fisiologia da produção de hortaliças em ambiente protegido. Horti Bras 18: 26-33. (CD-ROM).

Carrijo AO, Vidal MC, Reis NVB dos, Souza RB DE AND Makishima N. 2004. Produtividade do tomateiro em diferentes substratos e modelos de casas de vegetação. Horti Bras 22: 5-9.

CostA CP DA. 2005. A evolução da alfacicultura brasileira. Horti Bras 23. (against-layer).

EHLERS E. 1999. Agricultura sustentável: origens e perspectivas de um novo paradgma. Agropecuária, Guaíba: Agropecuária, $157 \mathrm{p}$.

Fukai S AND TREnbath BR. 1993. Processes determining intercrop productivity and yields of component crops. Field Crops Res 32: 247-271. 
Hiebsch CK ANd McCollum RE. 1987. Área × time equivalent ratio: a method for evaluating the productivity of intercrops. Agron J 79: 15-22.

JETT LW, ChISM JS AND CONLEY SP. 2005. Intercropping systems for tomatoes within a high tunnel.

http://www.hightunnels.org/images/Assets

Oliveira FL DE, RibAs RGT, JUNQUEIRA RM, PADOVAN MP, Guerra GM, ALMEIDA DL DE AND Ribeiro R DE LD. 2005. Desempenho do consórcio entre repolho e rabanete com pré-cultivo de crotalária, sob manejo orgânico. Horti Bras 23: 184-188.

Rezende BlA, Alves PlCA And Cecílio Filho AB. 2003. Efeito inibitório dos extratos aquosos de folhas de tomateiro em plantas de alface. Horti Bras 21. (CDROM).

Rezende BLA, Canato GHD and Cecílio Filho AB. 2005. Influência das épocas de cultivo e do estabelecimento do consórcio na produção de tomate e alface consorciado. Cienc Agrotecnol 29: 77-83.

RICE EL. 1974. Allelopathy. Academic Press, New York, $353 \mathrm{p}$.
SinOQueT H AND CALDWEll RM. 1995. Estimation of light capture and partitioning in intercropping systems. In: Sinoquet H AND CRUz P (Eds), Ecophysiology of tropical intercropping. INRA, Paris, p. 79-98.

SouZA JL AND RESENDE P. 2003. Rotação, sucessão e consorciação de culturas. In: SouZA JL AND RESENDE P. Manual de horticultura orgânica. Aprenda fácil, Viçosa, p. 175-179.

Trani PE, Nagai H and Passos FA. 1997a. Tomate. In: Raij B VAN, CANTARElla H, QUaggio JÁ AND FURLANI AMC. Recomendações de adubação e calagem para o estado de São Paulo. IAC, Campinas, 184 p.

Trani PE, Passos FA and Azevedo Filho JA. 1997b. Alface, almeirão, chicória, escarola, rúcula e agrião d'agua. In: RaiJ B VAN, CANTARElla H, QUAGgio JÁ AND FUR LANI AMC. Recomendações de adubação e calagem para o estado de São Paulo. IAC, Campinas, p. 168-169.

TRENBATH BR. 1975. Diversity or be damned? Ecologist 5: 76-83. 